\title{
Spontaneous cytotoxicity of rheumatoid and normal peripheral blood mononuclear cells against 4 human lymphoblastoid cell lines
}

\author{
J. HIGHTON AND G. S. PANAYI
}

From the Department of Medicine and Guy's Arthritis Research Unit, Guy's Hospital Medical School, London $S E 1$

SUMMARY By measuring spontaneous cytotoxicity of unfractionated peripheral blood mononuclear cells from patients with rheumatoid arthritis and from normal individuals against 4 human lymphoblastoid cell lines we have been unable to demonstrate any preferential recognition of antigens on these cell lines by rheumatoid patients.

Man has a lymphocyte population which is spontaneously cytotoxic to in-vitro propagated tumour cell lines. This phenomenon is mediated by a nonB, non-T, Fc receptor bearing lymphocyte, the spontaneous killer (SK) cell. ${ }^{1} \wedge$ similar phenomenon in mice is mediated by the natural killer cell (NK) cell. ${ }^{2}$ The biological significance of these systems is unknown, but postulated roles have included tumour surveillance and defence against viral infection.

The nature of the target antigen which these cells recognise is unknown. However, SK cells preferentially kill some lymphoblastoid cell lines, especially those derived from tumour cells rather than by viral transformation of normal lymphocytes, ${ }^{3}$ and inhibition experiments in mice have implied a certain amount of specificity. ${ }^{4}$ Mechanisms controlling SK cells are not known, but Jondal and Targan $^{5}$ have postulated that antigens like those expressed on Epstein-Barr virus (EBV) transformed $B$ cell lines may be involved in the in-vivo generation of SK cells.

There is continuing interest in the possibility that rheumatoid arthritis may be caused by a virus. This has been heightened by the observation that about $70 \%$ of patients with rheumatoid arthritis have a serum antibody reacting with a nuclear antigen within lymphoblastoid cell lines containing EBV genome. ${ }^{6}$ Thus, since it is possible that antigens similat to those expressed on EBV transformed cell lines might be involved in the in-vivo generation of SK cell activity, and since there is evidence of a serological response in rheumatoid arthritis against

\section{Accepted for publication 28 September 1979}

Correspondence to Dr G. S. Panayi, Department of Medicine, Guy's Hospital Medical School, London SE1 9RT. nuclear antigens in EBV-containing lymphoblastoid cell lines, we decided to investigate SK cell activity against lymphoblastoid cell lines in rheumatoid patients.

\section{Materials and methods}

\section{PATIENTS}

The results presented are derived from testing peripheral blood mononuclear cells (PBM) from 51 patients with rheumatoid arthritis, 31 females and 20 males, mean age $57 \cdot 2$ years. All were suffering from definite or classical rheumatoid arthritis by ARA criteria ${ }^{7}$ except 2 who had probab!e rheumatoid arthritis. Thirty-four patients were seropositive and 17 seronegative. Most had severe active disease as reflected in a mean ESR of $35 \cdot 1$ and the fact that all except 17 patients were being treated with gold, D-penicillamine, or prednisone. Thirty-seven controls were tested, 20 females and 17 males, mean age $40 \cdot 5$, who were attending for treatment of noninflammatory rheumatological conditions, mainly back pain.

\section{CELL LINES}

Four cell lines were used in these experiments. These were selected to include $B$ and $T$ cell lines, lines positive and negative for EBV genome, and lines derived from tumour cells and by transformation of normal lymphocytes. The main characteristics of these cell lines are shown in Table 1. CCRF/CEM is an EBV genome negative $T$ cell line established from a patient with lymphocytic leukaemia in childhood. ${ }^{8}$ RAJI is a well known EBV genome positive B cell line established from Burkitt's 
Table 1 Characteristics of the 4 human lymphoblastoid cell lines used as target cells in the spontaneous cytotoxicity experiments. B . bone-marrow-dependent lymphocytes. T. . thymus-dependent lymphocytes

\begin{tabular}{lllll}
\hline \multicolumn{5}{c}{ Cell line } \\
\hline & CCRF/CEM & RPMI 8226 & RAJI & WIL \\
\hline Origin & Leukaemia & Myeloma & Burkitt's & Normal \\
Cell type & T & B & B ymphoma & B \\
EBV genome Negative & Negative & Positive & Positive \\
\hline
\end{tabular}

lymphoma. ${ }^{9-11}$ It is positive for Epstein-Barr virus nuclear antigen (EBNA) but does not express viral capsid antigen (VCA) or membrane antigen (MA) under normal circumstances. ${ }^{12}$ RPMI 8226 is an EBV genome negative $B$ cell line established from a patient with myeloma and produces free immunoglobulin light chains in culture. ${ }^{13}$ Wil is an EBV genome positive B cell line established from normal lymphocytes obtained from a patient with myeloid leukaemia at the Queensland Institute of Medical Research (hence QIMR Wil). ${ }^{14}$

\section{CELL CULT URE}

All cell lines were grown in static culture in Eagles suspension medium (Gibco) buffered with Hepes and bicarbonate and supplemented with $10 \%$ fetal calf serum, $2 \mathrm{mM}$ L-glutamine and antibiotics (gentamicin $40 \mu \mathrm{g} / \mathrm{ml}$ and amphotericin B $250 \mu \mathrm{g} / \mathrm{ml}$ ). All the cell lines except RPMI 8226 grow in suspension and were harvested twice weekly by removal of half their volume. RPMI 8226, which grows as an adherent monolayer, was harvested twice weekly by vigorous shaking and removal of a majority of the culture fluid.

\section{MEDIUM USED FOR ASSAYS}

Assays were carried out in Eagles MEM (Gibco), buffered with Hepes and bicarbonate and supplemented with $10 \%$ fetal calf serum, $2 \mathrm{mM}$ L-glutamine and gentamicin $40 \mu \mathrm{g} / \mathrm{ml}$ (TCM). The same batch of fetal calf serum was used throughout.

\section{LABELLING OF TARGET CELLS}

After one wash in fresh TCM 5-8 $\times 10^{6}$ lymphoblastoid cells were suspended in $0.1 \mathrm{ml}{ }^{51} \mathrm{Cr}$-sodium chromate solution (Radiopharmaceuticals, Amersham, CJS-IP, specific activity $1 \mathrm{mCi}$ in $1 \mathrm{ml}$ ). The mixture was incubated for one hour at $37^{\circ} \mathrm{C}$, cells washed 4 times in TCM and adjusted to a concentration of $3 \times 10^{5} / \mathrm{ml}$.

\section{SEPARATION OF PERIPHERAL BLOOD} MONONUCLEAR CELLS

Venous blood was collected in sterile containers with $10 \mathrm{U}$ heparin per $\mathrm{ml}$ of blood. Peripheral blood monomuclear cells (PBM) were harvested from Triosil/Ficoll gradients. ${ }^{15}$ Monocytes were not routinely removed.

\section{CYTOTOXIC ASSAY}

Assays were carried out in triplicate in $2.5 \mathrm{ml}$ capped plastic tubes (Seward Co. Ltd.) in a total volume of $400 \mu \mathrm{l} \mathrm{TCM}$ containing $3 \times 10^{4}$ target cells and $6 \times 10^{5}$ lymphocytes, a ratio of $20: 1$ effector to target cells. Cultures were incubated overnight at $37^{\circ} \mathrm{C}(14-16 \mathrm{~h})$, then terminated by centrifugation and removal of $200 \mu$ l supernatant into a separate tube. Both tubes were then counted in an LKB gamma counter for 5 minutes each. Controls included target cells alone in TCM for calculation of spontaneous chromium release, identical cultures freeze-thawed to determine maximum release, and mitogen-stimulated cultures. The mitogens used were PHA or con-A in optimal concentration for lymphocyte transformation.

\section{CALCULATION OF RESULTS}

Percentage chromium release was calculated as

$\%$ Cr release $=100 \times \frac{2 S}{S+R}$

where $\mathbf{S}=$ counts in supernatant

$\mathbf{R}=$ counts in residual volume.

Specific cytotoxicity was calculated as

sp. cytotoxicity $=100 \times \frac{\mathrm{T}-\mathrm{S}}{\mathrm{M}-\mathrm{S}}$

where $\mathbf{T}=$ mean $\%$ test $\mathrm{Cr}$ release of triplicates as calculated above, $\mathrm{S}=$ mean $\% \mathrm{Cr}$ release of 6 control cultures of target cells alone in TCM after overnight culture (spontaneous $\mathrm{Cr}$ release), $\mathrm{M}=$ mean \% Cr release of 6 control cultures of target cells alone in TCM after freezing and thawing 4 times and overnight culture (maximum release).

\section{EVALUATION OF RESULTS}

Results were rejected if spontaneous chromium release exceeded $35 \%$ or if mitogen-induced cytotoxicity did not exceed spontaneous cytotoxicity. Mean standard error of the mean (SEM) for each group of values from individual assays was calculated and varied from 0.7 to $1 \cdot 3$, average $1 \cdot 0$. Results from a few triplicates with SEM greater than 2.5 were rejected. Unpaired and paired Student's $t$ tests were used for statistical evaluation as indicated in the text.

\section{Results}

The results of cytotoxicity for PBM from rheumatoid and normal individuals against the 4 cell lines are shown in Fig. 1. There is no significant difference 


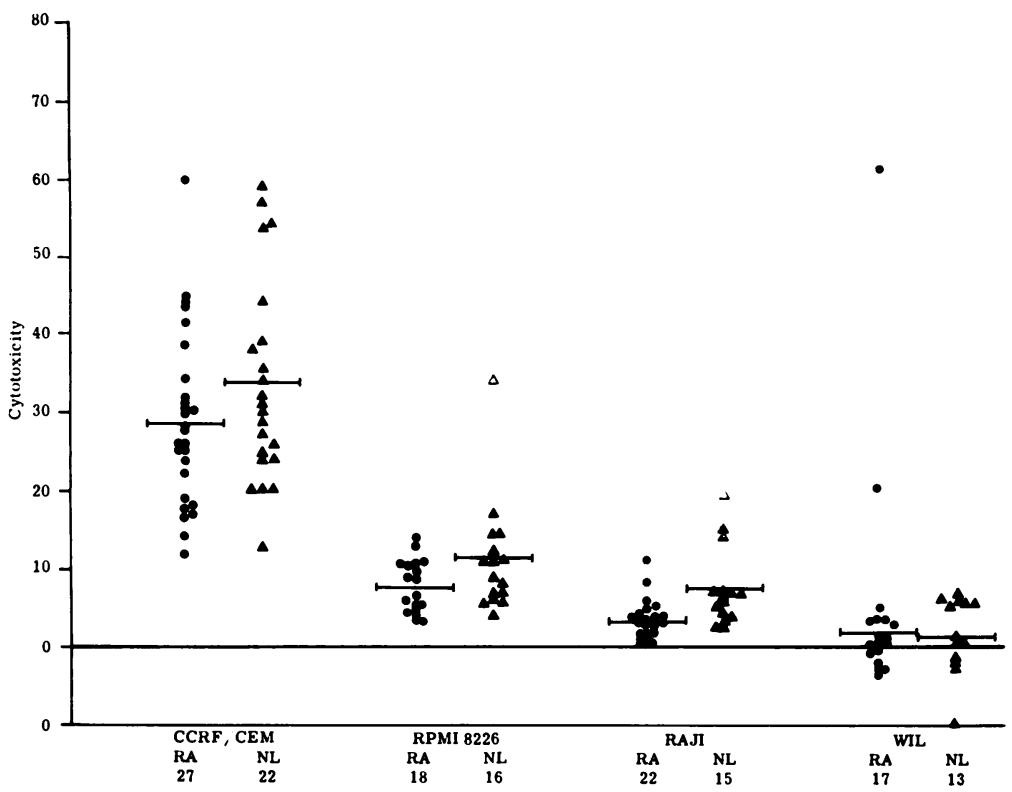

Fig. 1 Spontaneous cytotoxicity of peripheral blood mononuclear cells from patients with rheumatoid arthritis $(R A)$ and normal subjects $(N L)$ against the 4 cell lines. Bars represent mean cytotoxicity for all subjects except mean for rheumatoids with Wil which excludes the highest value, which is possibly anomalous. There is no significant difference between spontaneous cytotoxicity for rheumatoids and normal for any of the cell lines by Student's $\mathrm{t}$ test.

in spontaneous cytotoxicity between the rheumatoid patients and normal persons for any of the cell lines. It can be seen from Fig. 1 that there was a wide variation in cytotoxicity particularly for CCRF/ CEM in both the rheumatoids and the normals. This scatter is due to variation between individuals in the figure, though there was also some variation in cytotoxicity by PBM from the same individual when tested on different occasions. Results for RPMI, RAJI, and Wil are more closely grouped than for CCRF with the exception of a few markedly higher results. Subjects who showed high cytotoxicity against one cell line tended to show high levels against the other cell lines, suggesting that this was not a specific phenomenon (results not shown).

The 2 highest values for spontaneous cytotoxicity against Wil were shown by patients with rheumatoid arthritis. One rheumatoid patient showing a value of 20.1 with Wil also had a high value of 59.8 against CCRF. The other extremely high value of 60.7 against Wil was determined solely against this cell line and cannot be compared with cytotoxicity to other cell lines simultaneously. However, it may well be anomalous, as this patient previously showed a value of $12 \cdot 4$ (not shown as excluded by high spontaneous chromium release). At the time of the high value the patient's clinical status had shown no obvious change and she was not suffering from an obvious viral infection. She had recently had a test injection of sodium aurothiomalate, but other patients on this therapy showed results within the normal range. Addition of sodium aurothiomalate up to $100 \mu \mathrm{g} / \mathrm{ml}$ to cultures in vitro had no significant effect on cytotoxicity (results for 7 RA subjects, 6 normal subjects not shown).

\section{Discussion}

No difference has been shown between the spontaneous cytotoxicuty of peripheral blood mononuclear cells from patients with rheumatoid arthritis or from controls against the 4 cell lines tested. Though a positive result might have indicated a host response against lymphoblastoid antigens, the significance of a negative result cannot be so easily interpreted, while the mechanism by which SK cells recognise their targets is unknown. Thus, although rheumatoid patients do not preferentially kill cell lines positive for EBV genome, this cannot be taken as direct evidence that this agent could not play a role in the pathogenesis of RA, although other evidence against this hypothesis has recently been presented. ${ }^{17}$

There are a number of other factors to be considered. Although 2 groups were able to demonstrate increased killing of EBV-containing lymphoblastoid cell lines during active infectious mononucleosis using unfractionated peripheral blood leucocytes, ${ }^{18} 10$ a further group was able to demonstrate this effect only after removal of complement receptor bearing cells. ${ }^{20}$ Thus it is possible that a response of a subgroup of cells would be masked by nonspecific cytotoxicity in the experiments reported here. Interestingly, the increased cytotoxicity found 
during active EBV-induced infectious mononucleosis and thought to be a specific effect of circulating atypical $\mathbf{T}$ blast-like cells, has recently also been found in cytomegalovirus mononucleosis, again casting some doubt on the specificity of this finding. ${ }^{21}$ In both cases increased cytotoxicity was present only during actual infection and returned to normal levels during convalescence.

Of potential interest in this study were 2 rheumatoid patients showing high levels of cytotoxicity against Wil. However, one of these also showed a high level of cytotoxicity against CCRF, suggesting this might be a nonspecific effect, and the other value appears possibly anomalous in that the same patient had previously shown a value within the usual range, and no readily identifiable factors were associated with the second high value.

In general, results for rheumatoid patients in this study are similar to others previously reported for normal subjects. Thus the tumour cell line CCRF/ CEM is relatively well killed, whereas Wil, derived from normal lymphocytes, is not significantly killed. RAJI is poorly killed but is known to be an exception to the rule that tumour cell lines are well killed in comparison to lines derived from normal lymphocytes. $^{3}$ RPMI 8226 is an intermediate position. Thus, in studying cytotoxicity of unfractionated PBM from rheumatoids and normals against 4 lymphoblastoid cell lines we have been unable to demonstrate any increase in cytotoxicity amongst the rheumatoids, either overall or against particular cell lines, and so, using this rather limited system, we have not been able to show preferential recognition of antigens on these cell lines by rheumatoids.

We thank Dr M. Steel of the MRC and Population Cytogenetics Unit, Edinburgh, and Professor M. Epstein, University of Bristol Medical School, for their kind help in supplying the cell lines used in these experiments. We should also like to thank Dr R. Grahame and Dr T. Gibson, who allowed us to study some of their patients, and $\mathrm{Dr}$ Arlene Unger for helpful advice in the preparation of the manuscript. This study was funded in part by a grant from the Arthritis and Rheumatism Council.

\section{References}

1 Pross H, Baines M. Spontaneous human lymphocyte mediated cytotoxicity against tumour target cellsa short review. Cancer Immunol Immunother 1977; 3: 75-85.

2 Lotzova E, McCredie K B, Natural killer cells in mice and man and their possible biological significance-a short review. Cancer Immunol Immunother 1978; 4: 215-21.

3 Jondal M, Spina C, Targan S. Human spontaneous killer cells selective for tumour-derived target cells. Nature 1978; 272: 62-4.
4 Welsh R M, Zinkernagel R M. Heterospecific cytotoxic cell activity induced during the first 3 days of acute lymphocytic choriomeningitis infection in mice. Nature 1977; 268: 646-8.

5 Jondal M, Targan S. In vitro induction of cytotoxic effector cells with spontaneous killer cell specificity. $J$ Exp Med 1978; 147: 1621-36.

- Alspaugh M A, Jensen F C, Rabin H, Tan E M. Lymphocytes transformed by EBV. Induction of nuclear antigen reactive with antibody in RA. I Exp Med 1978; 147: 1018-27.

7 Ropes M W, Bennet G A, Cobb S, Jacox R, Jessar R A. Diagnostic criteria for RA. Ann Rheum Dis 1959; 18: 49-51.

8 Foley G E, Lazarus H, Farber S, Uzman B G, Boone B A, McCarthy $R$ E. Continuous culture of human lymphoblasts from peripheral blood of a child with acute leukaemia. Cancer 1965; 18: 522-9.

9 Epstein M A, Achong B G, Barr Y M, Zajec B, Henle G, Henle W. Morphological and virological investigations on cultured Burkitt tumour lymphoblasts (Strain RAJI). J Nat Cancer Inst 1966; 37: 547-59.

10 Hampar B, Derge J G, Martos L M, Walker J L. Synthesis of Epstein-Barr virus after activation of the viral genome in a 'virus negative' human lymphoblartoid cell (RAJI) made resistant to 5-bromodeocyuridine. Proc Nat Acad Sci USA 1972; 69: 78-82.

11 Gerber P. Activation of Epstein-Barr virus by 5-bromodeoxyuridine in 'virus free' human cells. Proc Natl Aead Sci USA 1972; 69: 83-5.

12 Nilsson K, Andersson L C, Galmberg C G, Wigzell H오 Surface patterns of normal and malignant human lym phoid cells II. B cells, B blasts, and Epstein-Barr virus (EBV)-positive and negative B lymphoid cell lines? Int J Cancer 1977; 20; 708-16.

13 Matsuoka Y, Moore G E, Yagi Y, Pressman D. Production of free light chains of immunoglobulin by a haematopoietic cell line derived from a patient with multiple myeloma. Proc Soc Exp Biol Med 1967; 125: 1246-50.

14 Pope $\mathrm{J}$ H. Establishment of cell lines from Australian Leukaemic patients: presence of a herpes-like virus. Aust J Biol Med Sci 1968; 46: 643-5.

15 Boyum A. Isolation of mononuclear cells and granulocytes from human blood. Scand J Clin Lab Invest 1968; Suppl. 97, 21: 77-89.

16 Alspaugh M A, Tan E M. Antibodies of cellular antigens in Sjogren's syndrome. J Clin Invest 1975; 55: 1067-73.

17 Elson C J, Crawford D H, Bucknall R C, et al. Infection with EB virus and rheumatoid arthritis. Lancet 1979; 1: 105 .

18 Royston I, Sullivan J L, Periman P O, Perlin E. Cell mediated immunity to Epstein-Barr-virus-transformed lymphoblastoid cells in acute infectious mononucleosis. $N$ Engl J Med 1975; 293: 1159-63.

19 Hutt L M, Huang Y T, Dascomb H E, Pagano J S. Enhanced destruction of lymphoid cell lines by peripheral blood leukocytes taken from patients with acute infectious mononucleosis. J Immunol 1975; 115 : 243-8.

20 Svedmyr E, Jondal M. Cytotoxic effector cells specific for B cell lines transformed by Epstein-Barr virus are present in patients with infectious mononucleosis. Proc Nat Acad Sci USA 1975; 72 : 1622-6.

21 Lemon S M, Hutt L M, Huang Y T. (1977). Cytotoxicity of circulating leukocytes in cytomegalovirus moonnucleosis. Clin Immunol Immunopathol 1977; 8 